\title{
Management: everything I wanted to know, but was too afraid to ask ... .
}

This article explores some basic questions about management and reveals that psychiatrists may already have a head start in management. The aim is not to make good psychiatrists into managers, but to enable good psychiatrists to provide good mental health care.

\section{What is management?}

Management is taking a plan and making it happen. Good management inspires and involves other people.

People who are good at doing things are promoted to a position where they take responsibility for other people doing things. They move from being 'good doers' to 'managers of doers' (Nelson \& Economy, 1996). Sadly, 'good doers' are not always good 'managers of doers'. There may be several reasons for this. First, the criterion for promotion tends to be aptitude at doing things rather than any potential skill to manage other people. Second, people may be promoted without necessarily being told that they will be taking responsibility for other people's work. Third, people may not be taught how to manage. They may well be too afraid to ask.

Things are changing for the better. Management is now firmly on the agenda for postgraduate training. Trainees in the specialist registrar grade are prompted to 'find out about management'. Attending a management course, shadowing a manager or undertaking a management project are all good places to start. Psychiatric trainees have a head start over their colleagues in other specialities. Yet as 'managers of doers' they will still need additional skills to get tasks done. This paper will address each of these points before considering why management skills are becoming increasingly important.

\section{In what ways do psychiatrists have a head start in management?}

The skills required to motivate a reluctant patient to attend occupational therapy or take his or her medication are hard to define. In essence they are psychotherapy skills. Skills with patients could be transferred to different situations. A clinician skilled in helping individuals recognise and change aspects of their behaviour that are not effective, may also be able to manage poor performance as part of clinical governance.

Psychiatrists, unlike surgeons, operate on interventions, not cure. No one can cure the NHS. But it is not beyond intervention. Psychiatrists are used to doing as much as possible with limited resources in situations that have so far 'refused to budge'. They are also used to beginning a relationship in conflict - like a Mental Health
Act assessment - and then working towards a mutually beneficial end.

At its heart, management is about guiding, helping, encouraging and listening to people. These are not new skills for psychiatrists.

\section{What additional management skills do psychiatrists need?}

\section{Managing meetings}

Much of psychiatry involves managing meetings: care planning meetings, ward round meetings and, of course, meetings with patients. A meeting is, to a psychiatrist, what an operating list is to a surgeon. Many doctors are never taught how to manage a meeting. It is a skill that can be learnt. Tony White teaches the skill in the final two chapters of his book, Management for Clinicians (White, 1993). Some important points from these chapters are summarised in Box 1.

\section{Delegation}

Nelson and Economy (1996) describe delegation as "the manager's number one tool". Their 'six steps of delegating', summarised in Box 2, cover one page of a chapter that includes: what to delegate; what not to delegate; and the ways in which delegation goes wrong. "Beginning to delegate", they say, "is sort of like bungee jumping for the first time".

Chairing meetings and learning to delegate are not new topics for psychiatrists. Management training for psychiatrists may be about learning to do better what we do already.

\section{Leadership}

Leadership is fundamentally different to either management or administration. Managers make strategic plans, set objectives and coordinate. Administrators carry out policies. Leadership is discovering the route ahead, encouraging and inspiring others to follow (Stewart, 1989). As Stewart (1989) summarises, managers direct, administrators confirm in writing, whereas leaders point the way: "do not be afraid to think of yourself as a leader", she adds. In a good mental health team individuals may work well at their own tasks. But in a well-led team the consultant creates a shared vision towards which each member of the team pulls together to provide a better mental health service.

Leadership is most needed in times of uncertainty. The National Association of Health Authorities and Trusts 
Box 1. Managing meetings

(adapted from White, 1993)

(a) Most hospital meetings take twice as long as necessary.

(b) The length of a meeting is proportional to the number of people attending.

(c) Only those who can influence the fulfilment of the objective should attend the meeting.

(d) Any meeting you attend is your meeting too.

(e) You should always go to the meeting knowing what you want to achieve.

(f) Spend more time in preparation and less in the meeting.

(g) To share work and responsibility you must have small groups.

(h) Opposition can be overcome by including opponents in the discussion.

(i) As chair of the meeting the less you say, the greater your strength.

(j) Some committees get into a habit of meeting even though they may not have any real purpose.

(NAHAT) has reported on the problems of under-funding, low morale and poor communication currently faced by adult mental health services. 'Strong leadership and sound management' is the resonating cry throughout the NAHAT plan for change (Moore, 1997). Managers cannot lead a service out of its problems. They can direct, and they may direct well. However, the whole enterprise will fail without leadership at the local level. Only clinicians can lead the service because clinicians work at the point at which the patients meet the service.

\section{Why are management skills increasingly important?}

The Government's 10-year plan, A First Class Service (Department of Health, 1998a), introduces a new management system of standard setting and monitoring. For some doctors this will be completely new. This is not so for psychiatrists. For example, all doctors will soon be responsible to a commission - the Commission for Health Improvement. In their work with detained patients, psychiatrists have been responsible to a commission for 17 years - the Mental Health Act Commission. Similarly, care planning meetings, user involvement and multi-disciplinary teamwork will become as familiar outside psychiatry as they are within it.
Box 2. The six steps of delegation (adapted from Nelson \& Economy, 1996)

(a) Communicate the task.

(b) Furnish context for the task. Explain why the task needs to be done, its importance ... and possible complications.

(c) Determine standards.

(d) Grant authority.

(e) Provide support.

(f) Get commitment.

What will be new for psychiatrists is inter-agency working. This will begin with the NHS and social services working more closely together (Department of Health, 1998b). Inter-agency working will extend to include voluntary agencies, the police and probation services. This will be as new for us as multi-disciplinary teamworking was in the 1980s. Change will require all the management skills referred to in this paper - but most of all it will require leadership.

\section{Comment}

Management is already an important part of a clinician's work. Psychiatrists may already have a head start in management. This is no cause for complacency. With skills in managing meetings, delegation and especially leadership, psychiatrists can make a success not just of multidisciplinary but multi-agency care. As Kennedy (1997) quotes Dr Kendell, the former president of the Royal College of Psychiatrists, "It may be more important for psychiatrists to know the $A B C$ of leadership than the first-rank symptoms of schizophrenia".

\section{References}

DEPARTMENT OF HEALTH (1998a) A First Class Service. Quality in the new NHS. London: Department of Health.

- (1998b) Modernising Mental Health Services: Safe, Sound and Supportive. London: Department of Health.

KENNEDY, P. (1997) From problems to solutions. Psychiatric Bulletin, 21, 593594.

NELSON, B. \& ECONOMY, P. (1996) Managing for Dummies. Foster City: IDG BooksWorldwide, Inc.

MOORE, W. (1997) Mental Health Care: from Problems to Solutions. National Association of Health Authorities and Trusts Research Paper No. 23. Birmingham: NAHAT.

STEWART, R. (1989) Leading in the NHS: A Practical Guide. London: Macmillan.

WHITE,T. (1993) Management for Clinicians. London: Edward Arnold.

Roger Denny Specialist Registrar, Cedar House, Blackberry Hill Hospital, Manor Road, Fishponds, Bristol BS162EW 